\title{
STUDY OF HEPATITIS B IN SCHOOLCHILDREN
}

$\mathrm{H}$ orizontal (non-sexual, perinatal or parenteral) transmission of hepatitis B infection may sometimes occur in schools even in countries with low endemicity but where there are small numbers of carriers among the students. Horizontal transmission is documented in households where one person is a carrier but the degree of infectivity of individual carriers, even those who are $\mathrm{HBe}$ Ag-positive, may vary widely.

Horizontal transmission of hepatitis B infection has been reported among schoolchildren in New Zealand. But there is little evidence of horizontal transmission between high- and low-carrier rate groups in Australia so routine vaccination of infants in the general population is not advocated. The Australian studies have involved a mixed-race community in Brewarrina, NSW $^{1}$, and schoolchildren in the Kimberley region of Western Australia'. A third study, soon to be published, was carried out in rural $\mathrm{NSW}^{3}$ and the National Health and Medical Research Council is supporting a Darwin survey, the results of which have not yet been made public. No attempt had been made to survey schoolchildren in the major urban population centres to help formulate vaccination policy for the whole of Australia.

Children of any race who acquire hepatitis B infection very early (at less than five years of age) probably have a higher risk of becoming chronic carriers of the virus and of developing serious long-term sequelae. Review of data from highly endemic areas has emphasised the importance of documentation of the levels of horizontal transmission among young children. The mode of transmission in these circumstances has not been clarified but is suggested to be by saliva or blood from skin abrasions.

Early in 1990 it was decided to study horizontal transmission of hepatitis B in Sydney schoolchildren. The best study design would have been one in which a cohort of low-risk children was followed from birth through pre-school and primary school, comparing infection rates and outcome between those in low-risk environments and those in high-risk environments. Such a study would have had to involve several thousand children and would have been time-consuming and costly.

A reasonable starting plan for a survey of horizontal transmission was therefore a cross-sectional serological study sampling children in the last year of primary school (aged about 12 years). These children have had a long period of school and in some cases pre-school to be exposed to horizontal risks. A plan was developed to sample a group of 750 low-risk children (children of ethnic groups with a carriage rate of less than 5 per cent) in 'low-risk' schools (schools with fewer than 5 per cent children from ethnic groups with more than 10 per cent carriage rate); and, 750 from 'high-risk' schools (more than 20 per cent of children from ethnic groups with more than 10 per cent carriage rate). A similar number of high-risk children (children of ethnic groups with a carriage rate of more than 10 per cent) would be sampled from the same 'high-risk' schools. The Director General of School Education gave permission for the studies.
The Sydney survey began in August 1990, at the beginning of the third school term. A group of schools has been chosen for the control arm of the study, mainly from the northern metropolitan area. All children taking part are volunteers whose parents have given written informed consent. Nurses and doctors from The Children's Hospital, Camperdown, collect venous blood from the children during school hours. There has been excellent co-operation from the schools and a good participation rate from the children. Some demographic data are being collected as well as information about the schools' lifestyles (such as types of games). The sera are being tested for hepatitis B markers and parents will be given their child's results, which will be confidential. Counselling will be available for the families of chronic carriers. Schools will not be given individual results but will be informed of the overall results of the survey.

Collection of sera from the control group has been completed this year in the fourth school term.

Collections from children in the 'high-risk' schools will be made in the first part of 1991 . The project is jointly funded and supported by the NSW Health Department and The Children's Hospital. Results will be available promptly and will be helpful in evaluating whether universal hepatitis B vaccination is needed.

\section{Margaret Burgess}

Physician in Preventive Medicine (Communicable Disease) The Children's Hospital Camperdown NSW

1. Campbell DH, Sargent JW, Plant AJ, The prevalence of markers of 1. Campbell DH, Sargent JW, Plant AJ, The prevalen community, Med J Aust 1989; 150:489-492.

2. Gill JS, Bucens M, Hatton M, Carey M, Quadros CF, Markers of hepatitis B virus infection in schoolchildren in the Kimberley, Western Australia, Med J Aust 1990; 153: 34-37.

3. Campbell DH, Plant AJ, Sargent JW, Mock PA, Barrett ER, Archer $\mathrm{KH}$ Hepatitis B infection of children in a mixed race community in western New South Wales, Med J Aust 1990; in press.

4. Davis LG, Weber DJ, Lemon SM, Horizontal transmission of hepatitis $B$ virus. Lancet $1989 ; 1$ : $889-893$.

\section{FACT SHEETS FOR NSW}

With this issue of the Public Health Bulletin readers will find the first of a series of NSW Health Indicator Fact Sheets being produced by the Epidemiology and Health Services Evaluation Branch.

Fact Sheets will provide information on priority health goals in a format which is easy to use and understand. Fact Sheet No $90 / 1$ is about the main cause of death in NSW - ischaemic heart disease - and includes time trends, age and sex differences and comparisons between health areas and regions.

Send your comments on the Fact Sheets to Judy Jones, Health Department Epidemiology Branch, Locked Bag, PO Box 961, North Sydney, 2059. The facsimile number is: (02) 3919232. 